\title{
A Nation That Won't Stop Growing: Demographic Dividend or Demographic Bulge?
}

\author{
Ehizuelen Michael Mitchell Omoruyi* \\ Zhejiang Normal University, Public University in Jinhua, China
}

*Corresponding author: Ehizuelen Michael Mitchell Omoruyi, Center for Nigerian Studies at the Institute of African Studies, Zhejiang Normal University, Public University in Jinhua, China

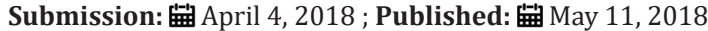

\section{Introduction}

The 28th African Union Summit declared "Harnessing the Demographic Dividend through investments in youth" as its theme, which links the "Agenda 2063" that offers a comprehensive development vision for Africa. Will this development help nurture young Nigerian entrepreneurs as the next generation of hunger fighters? Notably, Nigerian youth faces numerous challenges and opportunities in the fields of skills training, technology, entrepreneurship, agribusiness, advocacy, and political involvement. Hopes that Nigeria's dramatic population bulge may create prosperity seem to have been overdone. It is time for development economists to look beyond the stylized facts to the dire realities of Nigeria's frustrated youth and burgeoning informal economies. Although development economists talk about a demographic dividend for Nigeria, however, what Nigeria has now is not a 'dividend' but a youth population 'bulge'. A dividend is the outcome of your investments. If you invest well, you get outcomes. The numbers of Nigerian population are eye-catching with a young and growing diverse population. According to United Nations data, Nigeria is heavily populated and the country population is growing rapidly; Nigeria's population is currently the seventh largest globally and is growing at an average rate of 2.7 percent per year.

The population is estimated to be 203 million in 2025 and 279 million in 2050, compared to other African nations, making over 20 percent of the total African population. It is also young with 70 percent of people under the age of 30. Consequently, the population of Nigeria is projected to surpass that of the United States shortly before 2050, at which point it would become the third largest nation globally. Over two years ago, the speedy expansion of Nigeria's population was touted as one of the attractions drawing investors and multinationals to Nigeria. Chief executives and economists talked up the potential of a hopeful, youthful population wanting to open bank accounts, buy the latest smart phones and splurge on consumer goods. However, the drop of commodity prices and resulting economic slowdown in Nigeria has refocused attention on the risks connected with a smelling youthful population, which are unemployed, trapped in poverty, frustrated and risking their lives on perilous journeys in search of better life in Europe. Pools of idle youth are the magnets for recruiters from rebel or extremist group or even sold as slaves in Libya. Likewise, this presents a problematical picture for the Nigerian government, because according to National Bureau of Statistics (NBS), the unemployment rate augmented from 14.2 percent in Q4 2016 to 16.2 percent in Q2 2017 and 18.8 percent in Q3 2017. The number of people within the workforce who are unemployed or underemployed augmented from 13.6 million and 17.7 million respectively in Q2 2017, to 15.9 million and 18.0 million in Q3 2017.

Total unemployment and underemployment combined augmented from 37.2 percent in the previous quarter to 40.0 percent in Q3 2017. It is anticipated that more working-age youth will enter the labour force which will continue to pose more challenges. Limited labour-intensive activities, an educational curriculum with little applicability to the job market, a limited number of technical and vocational institutions have exacerbated this situation. Nigerian youthful population is the asset of the nation but if the government neglect them without investing in them it might turn out to be a tragedy. For that reason, the solution to closing the unemployment gap among Nigerian youth lies not on charity but on "sharity", which is knowledge sharing. Knowledge sharing that focuses on creating capacity and empowering Nigerian youth to be "job-creators" rather than "job-beggars" is necessary for turning Nigeria's population bulge into a demographic dividend which in turn, will reduce poverty. The question we keep on hearing is how can Nigeria government attain the desired outcome? Nigerian leaders should realize that addressing the scourge of turning Nigerian population bulge into demographic dividend requires that we look beyond the problem and learn from China's model as well as face the realities.

China enjoyed this demographic dividend in the nearly four decades, which was why China was considered a labour-plentiful nation. Arguably, unlimited and cheap labour supply from the agricultural sector with low productivity to industrial sector with high productivity contributed enormously to the economic rise of China in the process of the Chinese exported-oriented 
industrialization. According to Cai and Wang, China's demographic dividend contributed 26.8 percent to the Chinese per capita GDP growth between 1982 and 2000. There is, however, room regarding learning from China on how Nigeria can attain a successful demographic dividend. I think Nigeria-China collaboration in the area of knowledge sharing can be a good starting point. The unanimous decision at the last FOCAC meeting in South Africa in 2015, where President Xi Jin ping promised more cooperation between China and Africa in education and training confirm China's awareness to the importance of knowledge sharing in turning Nigerian population bulge into a demographic dividend. In the past, China has given concessional loans to African nations, including Nigeria, but nowadays, China wants African people to have the capacity to create a demographic dividend, that is why training which comes in form of knowledge sharing is now the core in China-Africa cooperation. Nigerian government can capture this opportunity by engaging with China to strengthen mutual learning. This is meant to advance common progress that will, in turn, help to address youth entrepreneurship and capacity building.

While the Nigeria-China economic relation is just beginning to shift, opportunities are emerging for forward-looking investors mindful of microeconomic changes. The concerns among numerous development economists are whether Nigerian government can capture this opportunity to harness the nation's demographic dividend, maximize potential gain in order to move numerous people out of poverty in the coming decades. To capture these opportunities, Nigerian government needs to create targeted youth programmes aimed at assisting business persons via capacity building and seed financing which can be stretched to cover diverse regions of Nigeria with a measurable outcome. It will be remarkable if Nigeria can establish a national skills development framework as stated by Olusegun Omisakin, head of research at the Nigerian Economic Summit Group (NESG) to address the skills deficit and support Nigeria economic expansion. On the part of the government, according to a report titled Nigeria's economic displays strong economic growth in 2017 from Oxford Business Group, the report asserts that broader efforts have also been taken to accelerate growth in the coming years, with a focus on import substitutions, industrialization, diversification, and export orientation. The measures come under the aegis of the Economic Recovery and Growth Plan (ERGP), a medium-term strategy stretching from 2017 to 2020.

The strategy comprises of taking a holistic approach to monetary, fiscal, and trade policies, diversifying government revenues away from dependency on oil, cutting costs and privatizing government assets. The report further states that the ERGP is designed to align with formerly announced programmes. For instance, its strategies follow numerous goals outlined in the Vision 2020 strategy, which aims to make Nigeria one of the 20 largest worldwide economies, with a minimum GDP of $\$ 900$ billion and yearly per capita income of $\$ 4000$. The ERGP suitably centres on private sectorled economic diversification, with the government promoting job opportunities, bolstering the business environment and providing the required infrastructure. Although Nigerian government is making all these key changes to create a recovery in the economy. However, it is instructive to note that a good policy is a policy that translates government goals into programmes and a policy is only successful when it delivers the desired result. Therefore, unless Nigerian government delivers the desired result by strengthening its institutional capacity, ensuring the right conditions, as well as implementing the right macroeconomic policies for realizing the demographic dividend at present and in the future, Nigeria's demographic change narrative might just be a tale of missed opportunity.
Creative Commons Attribution 4.0 International License

For possible submissions Click Here
Submit Article

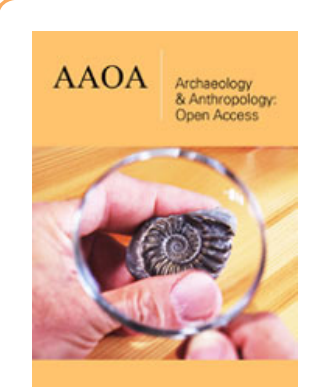

\section{Archaeology \& Anthropology: Open Access}

\section{Benefits of Publishing with us}

- High-level peer review and editorial services

- Freely accessible online immediately upon publication

- Authors retain the copyright to their work

- Licensing it under a Creative Commons license

- Visibility through different online platforms 